\title{
THE PROSPECTS OF ACCOUNTING AND ECONOMIC SYSTEMS IN THE ERA OF GLOBAL KNOWLEDGE ECONOMY
}

\author{
Babalola Yisau Abiodun ${ }^{1}$ \\ 'Accounting and Auditing Department East Ukrainian National University, Lugansk, Ukraine
}

\begin{abstract}
This article is devoted to the study based on secondary data of journal articles and websites. There is a growing interest in research on the treatment of intangible assets in the knowledge assets [intangible assets or intellectual capital (IC)] in this digital era, or a knowledge-based economy. Various observers describe today's global economy as one of the stages of the transition to a "knowledge economy" or "information society". But the rules and practices that determined success in the industrial economy of the 19th and 20th centuries to be changed in an environment where resources such as know-how are more critical than other economic resources. The paper highlights recent developments and thinking and provides guidance for the development of appropriate organizational strategies for success in the new millennium. It summarizes the main results of the research analyzes trends in accounting in the era of global knowledge economy.
\end{abstract}

Keywords: Accountin, Intellectual capital, Intangible assets, Economic resources, Organizational strategies, Global knowledge, Industrial economy.

\section{INTRODUCTION}

Management professionals in recent years highlighted the role of knowledge or intellectual capital in business. The value of high-tech companies such as software and biotechnology is not in physical assets, which are measured by accountants, but in their intangible assets such as knowledge and patents. In recent years, there is growing recognition authorities and international organizations that knowledge is a critical factor of production. Allee (2000) noted that the most common intellectual capital structure is still valid, there is a traditional view of the enterprise, which limits the type of business and economic analysis, which may be possible with an expanded view of value. The author argues that much of the talk about intellectual capital and intangible assets only serves to strengthen the existing thinking and mentality, offer alternatives to the expansion of the influence of intellectual capital and intangible assets that require potential areas of importance include: the business relationship; competence rights; internal structure , social citizenship, the environment and corporate identity.

This advanced form of intellectual capital allows us to start rethinking value and wealth at both the business and the macro-economic level. Rethinking value allows us to understand the 
essence of knowledge and intangible goods, and more fully appreciate the intangibles. Analysis of intellectual capital and intangible assets helps us to fully understand the company or the country in all its uniqueness, but only if we are to move forward to emphasize the advantages and differences that offer these prospects. The author warns that we must be vigilant in our thinking and constantly challenge our assumptions on the shortcomings and limitations in our models and be willing to experiment with different ways of studying the world.

When AmericanAirlines sold $18 \%$ of their electronic ticket reservation systems in October 1996, Lev took the opportunity to intangible assets as well as booking system basically has a large knowledge assets. He estimated that the cost of the booking system is $60 \%$ of the assets of Americans, far above the value of its fleet. He urged that companies should consider the value of knowledge assets before they do it, because any analysis of the impact of knowledge assets is a better indicator of profit and shareholder value, and the more important measure of the efficiency of the company, rather than specific assets.

Wurzburg (1998) notes that the current financial accounting and reporting system provides too little information about the kinds of intellectual assets, which would seem to play an important role in the knowledge economy. In addition, there has been little progress in changing the financial information, or improving non-financial information, although there are observable changes in methods of production, labor and skill requirements in the workplace.

Olsen (1999) notes that the traditional accounting based on the periodic historical, economic fundamentals and the application on the basis of measurements is replaced by a comprehensive, forward-looking, in real time, based on values, actionable knowledge, all due to technology, globalization and the so-called new economy. Financial information to be provided must have the following characteristics:

- Continuous and real-time information, not periodic reports

- Prospective reporting, as opposed to historical reporting

- Delivered on the basis of cost, as opposed to the cost basis

- Comprehensive, and not just financial information

- Easily accessed via the database, as opposed to paper statements.

Ivey (2002) notes that in today's economy hallmark between successful companies and unsuccessful people can be when the production technology becomes more homogeneous. Today many companies are reluctant to provide complete information about the IC in the annual report to external stakeholders. This is a lack of information about the value of the companies that may have more serious consequences that the parties make wrong or bad decisions. To remedy this situation, new tools must be developed that allow managers to define and measure IC Company and report it to the agreed framework. Valuation of intangible assets has become more and more significant and more complex study process at corporate bankruptcy and reorganization of the medium. Analysis and evaluation of intangible assets of the debtor provides a wealth of information and strategic benefits to debtors, creditors, and other parties. Accountants should be 
familiar with the assessment of the concepts and methodologies, as they are often involved in the bankruptcy and restructuring process.

\section{ACCOUNTING IN THE GLOBAL KNOWLEDGE ECONOMY}

Figure-1. Research framework

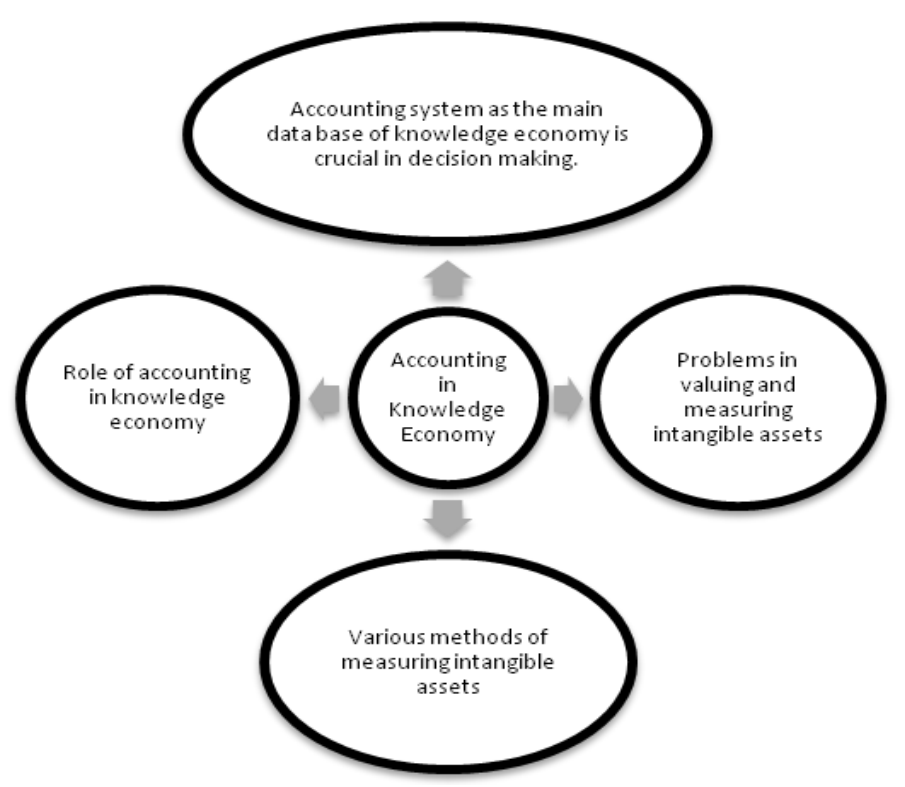

The role of accountants in business and industry is changing. Today the emphasis is more on information analysis and strategy setting, rather than the usual tasks of data collection and reporting. Sharma (2000) argues that the accountants and managers can unravel the meaning of knowledge management by monitoring and classification of Web information based on knowledge management. The author manages to give some idea of the problem of knowledge management, and several methods of measuring knowledge assets, but failed to provide a clear picture of what knowledge management and how organizations actually measure and value of their knowledge assets.

John and Seetharaman (2012) argues that the specific advantages of intangible assets usually come from human competence, which belongs to the man, not the company. The author suggests that intangible assets can be measured in terms of inputs, or investments and efforts to increase the value of economic activity, or they can be measured in terms of the creation of such investments and efforts. Input measures are not suitable for the measurement of intangible assets, for intangible investments just give people the opportunity to create intangible assets. As people will develop this ability depends on their commitment and effort.

In an economy based on knowledge, production and use of knowledge plays a predominant role in the creation of wealth. The knowledge economy is not only a digital economy, which includes the production and use of computers and telecommunications equipment. This is not exactly a network economy, which includes telecommunications and networking tools of growth, 
which are developed in the last decades and the impact on human progress. The knowledge-based economy is a much more complex and broad phenomenon. The Knowledge Economy is the "new economy", which differs from the traditional economy in several key respects:

1. Economy is not a deficit, and abundance. Unlike most of the resources that are destroyed when used, information and knowledge can be shared, and actually grow through the use of.

2. Reduced influence of the location. Using appropriate technology and methods, virtual markets can be created, which offer the advantage of speed and maneuverability.

3. Laws, barriers and taxes are difficult to apply solely on a national basis. Knowledge and information leaks, where demand is highest and the lowest barriers.

4. Price and value is highly dependent on context. The same information or knowledge can have completely different meanings to different people at different times.

5. Knowledge of systems and processes have higher values than in the minds of people.

6. Human capital, competence is a key component in the knowledge economy.

The new economy is based solely on the knowledge and intangible assets, not financial capital, and focus control is a long-term value creation, leading to an increase in market share. When we talk about the knowledge economy, we are talking about a world in which people work with their intellect, not your hands. This is a world where innovation is more important than mass production, a world in which investments are directed new concept, not new cars.

In the knowledge economy, companies are becoming more flexible, more adaptive, and more volatile in their structures, the production of "smart" products and services, which showed mass customization, customer involvement in product development and production, and to link suppliers, distributors and strategic partners in the overall chain fate. Emerging companies such as Microsoft, Google, FaceBook and other social media networks, created more intangible assets and value potential than traditional business.

\section{CREATION OF ASSETS TO BE RECORDED}

Created assets to be recorded, which provides each user with information to understand their business. The increase in fraud in the business world requires an entity attention and imposes a great responsibility for their financial practices. Business should be cleaned with a stream of transactions and adhere to the business and financial legislation, which really helps them to survive in the fast and ever-changing business environment. Accounting correctly helps us determine the current and future financial stability of the organization. Obviously, companies that comply with fair accounting practices, an unbeatable advantage over their competitors. They do not have any stress, and they have the opportunity to improve their solutions by understanding the current market situation.

A characteristic feature of intangible assets is that there is no direct connection between them and the financial results. Only through the actions and initiatives that combine the various intangible assets, financial outcome can be achieved. This calls for changes in the accounting system. The accounting profession should be more sensitive to the critical business requirements 
related to intangible assets. Accounting standards and conventions should reflect the dynamic nature of the business environment.

One of the main problems in the accounting system today is that it is still based on operations such as sales. In today's knowledge-based economy, a large part of the creation, or reduce the cost of transactions to occur before. For example, the successful development of the product creates a lot of value, but for actual transactions, such as sales, it may take years to materialize. This is the reason why the company is difficult to explain the presence of these intangible assets, as there is no market for intangible assets, and the market is something that provides value. Intangible assets, such as the opening of new products, software, trademarks, or unique organizational structures and processes that provide a competitive advantage are not traded in an organized market, as well as ownership of these assets are often not fully provided by the company. This creates difficulties in the assessment and measurement.

Another difficulty in measuring intangible assets is the lack of "scarcity". The deficit is a typical characteristic of the physical assets. In typical physical assets business income will increase if you can continue to invest in this business, but only to a certain level. For example, if a farmer who owns land (tangible assets), can increase revenue by using more workers or by investing in the best agricultural machinery. But at a certain point in time, the return of its investments will decline due to scarcity of the asset, which is called the "land." In a knowledge-based assets, such as books or software, it is completely different, as it can be copied unlimited and can be used to read by so many people who love to read. This refers to the knowledge of a man who has unlimited use. Thus, companies have less control over the intangible assets such as knowledge, which leads to a higher risk. It is therefore very difficult to detect and measure the value or the value of intangible assets. Intangible assets are still a new discipline, and not much is known about it at the moment. There is an ongoing debate on its definition, classification, components, value, communications strategy, and income, the best estimate basis and methods.

\section{CONCLUSION}

The various components of intangible assets are closely related and intertwined with other company resources. This relationship should be further investigated in order to get a complete picture of the cause and effect of intangible assets to the value of capacity building. Even in a mild recession that will differentiate the winners from the losers are the intangible values of innovation and performance that lead to new ideas, products and processes. Understanding these assets necessitates ways of assessing their value, which is important for reporting and business prospects. Some progress has been made, but much more remains to be done. Companies are afraid to reveal too much information about intangible assets, because information gives an idea of their competitive advantages. In addition, information on intangible assets can be easily manipulated. Therefore, companies prefer to start with improving their internal reporting on intangible assets. 


\section{REFERENCES}

Allee, V., 2000. The value evolution: Addressing larger implications of an IC and intangibles perspective. J. Intell. Capital, 1(1): 17-32.

Ivey, J., 2002. Accounting for knowledge. Corp. Financ., 208: 19-20.

John, R.R. and A. Seetharaman, 2012. The role of accounting in the knowledge economy. African Journal of Business Management, 6(2).

Olsen, C., 1999. Accounting for a new economy outlook, 67(1): 28-32.

Sharma, R., 2000. Unraveling the knowledge management puzzle. Chartered Account, 71(7): 44-45.

Wurzburg, G., 1998. Markets and the knowledge economy: Is anything broken? Can government fix it? J.Knowl. Manage., 2(1): 32-46. 